NASA Technical Memorandum 89872

AIAA-87-9203

\title{
High Temperature Solid Oxide Regenerative Fuel Cell for Solar Photovoltaic Energy Storage
}

\section{(AASA-TH-89872) EIGH TELPEEATUEE SCLID \\ CMIDE EEGBHERATIVE FOEL CELL FCE SCLAR \\ บ87-23020 \\ FHCTOVOLIAIC EN EECY STORACE (MASA) $19 \mathrm{p}$ \\ Arail: MIIS HC A02/AF 101 CSCL 10C $G^{3}$ unclas \\ $14 / 440074229$}

David J. Bents

Lewis Research Center

Cleveland, Ohio

Prepared for the

22nd Intersociety Energy Conversion Engineering Conference cosponsored by the AIAA, ANS, ASME, SAE, IEEE, ACS, and AIChE Philadelphia, Pennsylvania, August 10-14, 1987

\section{NMSA}


David J. Bents

National Aeronautics and Space Administration

Lewis Research Center

Cleveland, ohio 44135

\section{Abstract}

This paper describes a hydrogen-oxygen regenerative fuel cell (RFC) energy storage system based on high temperature solid oxide fuel cell (SOFC) technology. The reactants are stored as gases in lightweight insulated pressure vessels. The product water is stored as a liquid in saturated equilibrium with the fuel gas. The system functions as a secondary battery and is applicable to darkside energy storage for solar photovoltaics.

The system design, its component parts and their arrangement is presented. Forward and reverse operating cycles are described. Since the RFC is most applicable to operating regimes where reactant storage dominates system weight, the system uses the SOFC high temperature properties not to reduce radiator size but minimize reactant storage instead. Heat flow, mass, and energy balances are presented to characterize system operation and show how internal state and performance varies as reactant storage pressure rises and falls. Based upon these calculations, established mass models of the better-known system components, and the currently accepted projections for SOFC stack characteristics, the size and weight of this system is estimated over the range 10 to $300 \mathrm{kWe}$, for charge/discharge cycles up to 30 days duration (charging period roughly equal to or greater than the discharging period). Near-term aerospace SOFC technology (Argonne National Laboratory's Mod. O monolith) is used as the basis for characterization.

For solar PV application over the range investigated the system appears to be superior to alkaline RFC's and also quite competitive with advanced technology batteries and nuclear sources; demonstrating superior specific weight in the intermediate mission range of 3 to $72 \mathrm{hr}$ darkside. specific weight improves as charge/discharge time increases; the system weighs less than nickel hydrogen battery systems after $0.7 \mathrm{hr}$ darkside, maintaining a specific weight advantage over radioisotope thermal generators (RTG's) for discharge periods up to $72 \mathrm{hr}$.

\section{Introduction}

Solid oxide fuel cell technology is of interest to space power system developers because, if this technology is developed, its novel characteristics offer system-enabling capabilities not avallable from the more well-established fuel cell types. These capabilities include high power density (up to $8 \mathrm{~W} / \mathrm{cm}^{3}$ of stack is claimed), reduced internal resistance etc. resulting from the small cell dimensions, one piece construction from thin multiple layers of ceramic (hence the term "monolithic"), and direct waste heat removal by the reactant streams at elevated temperature $\left(1000{ }^{\circ} \mathrm{C}\right)$; leading to reduced radiator size, simplified reactant and thermal management. The
SOFC shares the same fundamental electrochemistry, thermodynamics of the better-known low temperature fuel cell technologies, but its solid state and faster kinetics should render it much less sensitive to variations in reactant composition, contaminants; thereby leading to system designs that are rugged, more compact, and less complicated. For energy storage RFC systems these characteristics translate to greater integration flexibility, resulting from a wider range of temperatures. pressures to work with for balancing flow, heat exchange during the optimization process for that particular application. Compared to the alkaline RFC, 1 the novel operating characteristics of SOFC's appear to confer system level advantages for energy storage which make it more attractive.

Consider the RFC system shown in Fig. 1 , designed to provide darkside energy storage for solar photovoltaic (PV) power. For space this is one of the most important applications since, with PV, the secondary battery is an indispensible element; there are inevitable sun/shade cycles for almost all missions of interest. A remote terrestrial (or Mars surface) energy storage system is used to illustrate the basic design; however, the cycle description and system characterization can be extended to all darkside applications.

\section{System Description}

The major elements of this system are the converter unit, storage tanks (for oxygen, the fuel gas, and product water), and a radiator. The storage tanks are pressure vessels; moderately insulated and of lightweight composite construction. The converter unit, fuel tank, and oxygen tank are connected together through hoses and are all at the same pressure (which ranges from 5 to $100 \mathrm{~atm}$ ). For sustained operating periods such as Mars or lunar night the converter and storage reservotis are separate; for applications covering shorter discharge periods a single pressure vessel might be used to enclose all three.

The fuel storage reservoir contains a saturated mixture of hydrogen gas and vapor and includes a sump for product water accumulation. Within its interior, connected through external hoses and wiring harness, are temperature, pressure, and relative humidity sensors, a fuel gas intake/outlet standpipe and a thermal control radiator. Water vapor content with in the tank is maintained at about 10 mol $\%$ by the release of controlled amounts of waste heat to its interior.

The oxygen tank is similar in form and equipment. It contains the (stochiometric) amount of pure oxygen matching the fuel gas' hydrogen content. The stored gas is dry. The oxygen tank is connected to the converter unit by a pressurized hose for reactant gas transport, plus two fluid hoses for thermal transport (the fuel tank connection includes a third liquid hose for product water transport). 
The converter is a sealed unit depicted schematically in Fig. 2 . Within the converter there is a high temperature section (SOFC stack and reactant preheat heat exchangers) surrounded by insulation, and a low temperature section (gas flow and fluid transport). The stack functions as both an electrolyzer and a fuel cell. similar to alkaline RFC systems, the stack is combined with a recirculating loop that removes product water and adds more fuel gas to the stream as hydrogen is consumed. A condenser combined with mechanical pump/separator is used to remove the water. Compared to the alkaline RFC, however, this recirculating loop operates at higher temperature, lower utilization, and a much higher flow rate per kilowatt since the fuel gas stream also removes the stack waste heat.

\section{Converter High Temperature Section}

Within the high temperature section, the SOFC stack is the element where electrochemical conversion actually takes place. It operates at $1273 \mathrm{~K}\left(1000{ }^{\circ} \mathrm{C}\right)$. It is a thinwall corrugated ceramic structure that in the Mod 0 embodiment (Fig. 3) resembles a compact crossflow heat exchanger. The stack is a bipolar array of individual fuel cells; the cells are sandwiched layers of alternating flat and corrugated thin sheets, sintered together to form a single piece that contains the entire array and all the individual cell elements (anode, electrolyte and cathode layers, the bipolar interconnects), which are themseives multilayer laminations of different ceramic materials which form the active cell components. In the ANL Mod 0 stack configuration the sandwiched corrugations are stacked at right angles to each other, forming alternating passages for fuel gas and oxygen so that the individual cells are parrallel in flow but connected electrically in series. The passages for fuel gas are open at both ends to allow the recirculating stream to pass through the stack; the oxygen passages are open at only one end.

The stack is bordered on four sides by two seperate sets of reactant preheat heat exchangers (RPHX's) for the oxygen and fuel gas streams; a manifold that splits the exhaust flow between them, and a plenum directing the fuel gas preheat exhaust stream around the oxygen side which is "dead-ended." Figure 4(a) shows the RPHX stack integration: Fig. 4(b) shows exhaust flow pattern through these heat exchangers. They control heat loss from the stack and reduce the inlet temperature gradient it must withstand. All heat exchangers are counterflow. Each $H X$ is split into two separate sections which are constructed of different materials according to the reactants and temperature ranges experienced. The RPHX section No. 1 for fuel gas also contains a feedwater heater/boiler ("steam leg") for condensate. Temperatures at the inlet and exit side of the RPHX can range from 355 to $750 \mathrm{~K}$; next to the stack they vary from 973 to $1273 \mathrm{~K}$.

The stack is also bordered top and bottom by metal current collector plates which contact the ceramic monolith stack through pads of nickel

felt. The entire high temperature section (stack, heat exchangers, and contacts) is surrounded by a substantial blanket of insulation to reduce stack temperature gradient, heat loss, and protect the low temperature components with in the converter.
Low Temperature Section

The low temperature section contains the waste heat and water removal portion of the recirculating loop. Temperatures in this section range from less that $300 \mathrm{~K}$, with in the condenser cooling loop when electrolys is begins, to $750 \mathrm{~K}$ at the condenser inlet during fuel cell operation. However, the pumps, valves, metering, and other mechanical components are located downstream where operating temperatures no greater than $450 \mathrm{~K}$ are experienced.

The pump/separator circulates the fuel gas. It provides enough pressure drop to allow flow to be diverted to and from the storage reservoir by proportional control valves located at the pump inlet and exit. On the other hand, oxygen flow is not mechanically pumped but driven by concentration gradient only.

The condenser is cooled by a pumped fluid loop that circulates through internal radiators in both pressure vessels before it reaches the main radiator. This thermal management system ultimately removes the stack waste heat and controls internal temperature, acting to maintain the desired (10 mol \% saturation) moisture content within the recirculating fuel gas and storage tank. Condenser exit temperature is controlied by modulating coolant flow (pump speed); internal radiator heat loads are separately adjusted via bypass. Waste heat, initially rejected by the stack at high temperature, is distributed throughout the system at a lower temperature via the condenser, finally exiting the system through the tank walls as well as the radiator. This system does not take advantage of the SOFC stack high temperature heat rejection capability to minimize radiator size, but condenses the product water to minimize reactant storage instead.

\section{System Operation}

The system operates like a secondary battery. It accumulates hydrogen and oxygen gas through vapor electrolysis during periods of sunlight. and discharges electricity during perlods of darkness through (fuel cell) consumption of these reactants. All energy for the electrolysis cycle is supplied by the photovoltaic array.

At the beginning of electrolysis most of the hydrogen and oxygen is liquid water at the bottom of the sump. Pressure inside the system is low (for the analysis it is $5 \mathrm{~atm}$ ). When the electrolysis cycle is complete the reactants are gases at somewhat higher temperature, and greatly increased pressure $(100 \mathrm{~atm}$, due to fixed storage volume). This situation reverses itself during (darkside) forward operation as hydrogen and oxygen gas are reacted to form steam and then condensed. The fuel gas is not pure hydrogen but contains some water vapor; a consequence of incomplete electrolysis but also necessary to maintain reducing atmosphere in the fuel gas stream. Typically at least 10 mol \% water vapor is required. To maintain vapor partial pressure corresponding to $10 \mathrm{~mol} \%$, storage and condenser exit temperatures are controlled to track internal pressure along the ( $10 \mathrm{~mol} \%)$ saturation 1 ine as it rises and falls. This temperature, which is also an indicator of reactant accumulation/depletion 
within the system, is essentially an equilibrium temperature since it changes relatively slowly with time.

\section{Regenerative Operation}

For purposes of analys is the electrolysis cycle begins at the sump. Liquid water at equilibrium temperature is pumped into the steam leg of the RPHX section No. 1, heated, and vaporized. The saturated vapor mixes adiabatically with the recirculating fuel gas stream ( $10 \mathrm{~mol} \%$ water vapor mixed with hydrogen slightly heated above saturation) and is further heated in RPHX section No. 2. The superheated steam/hydrogen mixture leaves this section and enters the stack at approximately $1000 \mathrm{~K}$. Vapor content is approximately 30 percent.

When the stack acts as an electrolyzer, water vapor in the recirculating stream is reduced to hydrogen and oxygen is formed in a separate stream. Energy for the electrolysis process is externally supplied. Voltage applied to the stack must overcome not only the electrochemical potential but also cell resistance and polarization losses. As a result, some waste heat is also produced in addition to the reprocessed reactants. In this system waste heat is used to vaporize and superheat the water before it is reprocessed; consequently a minimum, rather than a maximum, energy loss requirement is imposed on the electrolyzer. For example, the waste heat required to sustain condensate vaporization at $5 \mathrm{~atm}$ would be equivalent to $400 \mathrm{mV}$ of loss; at $100 \mathrm{~atm}$ on $1 \mathrm{y}$ $220 \mathrm{mV}$ would be needed. Fortultously, electrolysis polarization losses for SOFC appear to be we 11 within this range. 2 Table $?$ summartzes single cell performance when the stack operates as an electrolyzer.

The reprocessed fuel gas and oxygen streams leave the stack at $1273 \mathrm{~K}$ and enter their respective RPHX's. Both streams lose some heat to the recirculating inlet gas in RPHX section No. 2 , but most heat transfer takes place in section No. 1 where the condensate is vaporized. Final temperature of the reprocessed gas exiting the RPHX is 30 to $50 \mathrm{~K}$ above the recirculating stream and liquid water that entered initially.

The oxygen stream is pumped by positive concentration pressure gradient from the converter into its storage tank where it loses heat to the surroundings until equilibrium temperature is reached. The fuel gas stream on the other hand is drawn through the condenser, where it loses heat until its temperature is stabilized at equilibrium. It is then drawn into the pump/ separator, which forces it through a proportioning value that shunts a fraction of the recirculating flow to storage. The remaining flow continues in the recirculating stream.

Figure 5 shows state points, temperature, and flow distribution within the converter at the beginning of electrolysis. As the electrolysis cycle proceeds and more reactant gas is reprocessed, the system internal pressure slowly rises until it reaches $100 \mathrm{~atm}$ at the end of the cycle. Table 2 summarizes the change in converter performance, state points as internal pressure rises from 5 to $100 \mathrm{~atm}$.
Forward Operation

Fuel cell operation begins at the RPHX. Recirculating fuel gas and oxygen streams enter the RPHX at equilibrium temperature. There they are heated by the (recirculating return) exhaust gas to $973 \mathrm{~K}$ before they enter the stack.

When the stack acts as a fuel cell, reactants are converted to water vapor accompanied by the release of electrical energy and heat. The oxygen passages within the stack are "dead-ended;" that is, all the oxygen admitted to the stack is consumed. The recirculating fuel gas stream, on the other hand, passes through the stack losing only a fraction of the hydrogen it contains. As fuel gas passes through the stack, hydrogen is consumed and replaced with water vapor. The net effect is to lower the hydrogen content and increase the vapor content. Vapor content at the stack exit is approximately 30 percent, which translates to a net change, or cell utilization, of approximately 25 percent. Table 3 shows single cell performance (cell voltage, inlet and exit molar concentrations, thermal efficiency etc.) during stack forward operation. All of the waste heat produced by the stack is rejected to the recirculating steam, which experiences an approximately $300 \mathrm{~K}$ temperature $\mathrm{rise}$ to $1273 \mathrm{~K}$ at the stack exit. When the stream flows back out through the RPHX as exhaust, about half this waste heat is given up to the incoming reactants, cooling the exhaust to approximately $700 \mathrm{~K}$ before it reaches the condenser.

The condenser cools the exhaust to equilibrium temperature; from a mixture of super heated steam and hydrogen at the condenser inlet to a saturated mixture of hydrogen gas, water vapor, and liquid at the condenser exit. Condensation reduces the products of reaction to their most compact form, removing not only the waste heat remaining from fuel cell operation but also the heat of vaporization introduced earlier during the electrolysis cycle.

The saturated hydrogen/vapor/liquid is drawn out of the condenser by the pump/separator downstream. Makeup fuel gas from storage is introduced at the pump inlet through an admission valve, resulting in increased hydrogen flow but no change in molar composition. The pump/separator removes liquid entrained in the stream and sends it to the sump, while the gas continues to recirculate.

Figure 6 shows state points, temperature, and flow distribution within the converter at the beginning of forward operation. As the reactant gas is consumed, internal pressure slowly drops. Table 4 summarizes converter internal state and performance as the pressure falls from 100 to 5 atm.

\section{System Characterization}

The RFC system described here can be characterized on the basis of its conceptual design and operating cycles in order to establish a preiminary estimate of size and weight. This estimate is not a competitive evaluation pitting new technology against existing RFC systems but is an assessment of the new technology guaging its 
potential if successfully developed. The SOFC has not yet matured to the point where large stack arrays can be produced (arrays up to $5 \mathrm{kWe}$ have been tested but the ANL monolith considered by this analysis has only been built in sizes up to a few watts) but it is nontheless possible to make performance estimates for larger arrays now due to the modular nature of the SOFC stack and individual cell performance which has already been demonstrated. 3 These array performance extrapolations can be used to estimate overall performance and characteristics of the SOFC regen fuel cell because the other system components have been well-characterized; 1.e. they are we 11 enough understood that there is widespread agreement concerning their basis of estimation, modeling methodology. System designs configured for the end user are required early on for characterization, because they indicate whether or not the technology is worth developing for that application.

Based upon the operating cycle previousiy described, established mass models of the better known system components, and the currently accepted projections for SOFC stack characteristics, the size and weight of the various system components was estimated over the range of output power levels 10 to $300 \mathrm{kWe}$, and tabulated together to compose an overall estimate for the system, for charge/discharge cycles up to $500 \mathrm{hr}$ duration.

An example tabulation of the system component weights for a $10 \mathrm{kWe}$ Mars surface combined solar PV/regenerative fuel cell power system appears in Table 5. Assumptions exerting influence on overall system weight that were not directiy coupled into the cycle performance analysis were:

\section{Pressure Vessel Shell and Insulation Materials}

The storage tanks and converter structure/ containment pressure vessel shells were assumed to be of laminated wound graphite fllament/ polyamide stressed to $25 \mathrm{ksi}$. One centimeter of multifoll insulation, $0.11 \mathrm{gram} / \mathrm{cc}$, was included for interior lining. Design pressure was $100 \mathrm{~atm}$.

\section{SOFC Stack Stze and Weight}

The ANL Mod 0 monolith described in Refs. 3 and 4 was used. Key parameters are given in Table 6 .

\section{Radiator Size and Weight}

All radiators were pumped fluid loop, aluminum platecoli construction, specific weight of $5.8 \mathrm{~kg} / \mathrm{m}^{2}$ of surface area. The external radiator would be physically equivalent to the main radiator used by the alkaline RFC. 1 For lunar and planetary darkside heat rejection a background temperature of $20 \mathrm{~K}$ was assumed. Emissivity was 0.72 . Due to the low $(\sim 300 \mathrm{~K})$ rejection temperature at the lowest pressure, the external radiator turned out to be roughly as large as the converter unit itself.

\section{Solar PV Collectors}

The PV collector mass listed in Table 5 and shown also in Fig. 7 was based on the technology assessment of Ref. 5; approximately 50 percent solar flux reduction on Mars surface compared with Earth ${ }^{6}$ was also considered, resulting in an assigned value of 100 electrical watts per kllogram of solar array. The collector assembly was included as part of the overall power system shown in Figs. 1,7, and Table 5 but was not included in the RFC comparisons with other darkside energy storage systems shown subsequently.

\section{Heat Exchangers}

Heat exchanger assumptions were not a signifficant influence on converter weight. For a fuel cell system, the heat loads are equivalent to only a fraction of the electrical power transfer, and the operating cycle maintains stream-tostream temperature differences greater than $30 \mathrm{~K}$ everywhere. Using conservative values of mean effective heat transfer, heat exchanger packing density and specific weight, the combined weight of all heat exchangers remained less that 40 percent of the stack weight.

Figure 7 shows graphically how the weight of the major elements for a 10 kWe system (Table 5), including the PV array, changes as a function of the mission (darkside) time over the specified range. The analysis assumes that the daylight, or recharge time avaliable is roughly equal to, or greater than, the discharge time. If the PV array is removed, the remaining system weight can be attributed to darkside energy storage, which is characterizable as a secondary battery and can be directly compared to other forms of energy storage.

Figure 8 presents specific weight, kilograms per kllowatt delivered, of the energy storage system alone over the range 1 to $500 \mathrm{hr}$, for design power levels of $10,30,100$, and $300 \mathrm{kWe}$. Superimposed are (diagonal) lines of constant watt-hours per kllogram, an accepted universal figure of merit. Some established SOA values for commonly known storage technologies are: nickelhydrogen battery systems, $33 \mathrm{~W}-\mathrm{hr} / \mathrm{kg}$; solid metal flywheel rotors, $18 \mathrm{~W}-\mathrm{hr} / \mathrm{kg}$ and so on. The curve shape indicates a mass penalty associated with the fixed converter and radiator weight for short duration missions, but a benefit at longer mission times where reactant storage is a major component of the overall system. This can be attributed to the relatively high energy available from hydrogen/oxygen.

Figure 9 presents the same specific weight curve but overlays it with equivalent specific weight curves for three "rival" darkside energy storage systems within the same specified range. The electrochemical systems are selected for the comparison because they are presently deemed to be most competitive for the space PV darkside application. A constant slope of $33 \mathrm{~W}-\mathrm{hr} / \mathrm{kg}$ is superimposed representing SOA nickel-hyrogen battery systems. A constant slope of $100 \mathrm{~W}-\mathrm{hr} / \mathrm{kg}$ represents the advanced battery technology capability which may be achieved by high temperature sodium-sulfur battery systems. 7 The "minimum mass integrated system" alkaline regenerative fuel cell of Ref. 1 is also superimposed since it is similar, with a converter weight that is fixed and pressurized gas reactant storage that cycles between 4 and $20 \mathrm{~atm}$. Comparison is also made with nuclear sources. For sun/shade cycles approaching $100 \mathrm{hr}$, reactant storage dominates 
system weight to such an extent that the mass of the PV array used for changing the system can be neglected. The RTG specific weight used to represent nuclear systems is the GPHS program goal of $5.2 \mathrm{~kg} / \mathrm{w}^{8}$; this specific weight is also representative of a space reactor power system that uses a man-rated shield.

\section{Results and Summary}

The data show a clear region of interest for the high temperature solid oxide regen. fuel cell, where it extibits much lower specific weight than the other systems shown. This region falls somewhere between the 2 and $70 \mathrm{hr}$ sun/shade time; a time period out of the range of earth orbit applications, but well within the range of interest for Mars surface and remote terrestrial installations. On the other hand, lunar surface missions ( $327 \mathrm{hr}$ of darkness) falls into the domain of nuclear generation unless the solid oxide fuel cell RFC was synergistic with other on-site hydrogen/oxygen systems, or there were compelling reasons not to use nuclear for a lunar base.

It therefore appears that, within the application we have defined, the high temperature solid oxide regen. fuel cell has the potential to be very competitive with several of the energy storage technologies now extant or under development.

\section{References}

1. Hoberecht, M.A. and Rieker, L.L., "Design of a Regenerative Fuel Cell System for Space Station," Energy for the Twenty-first Century (20th IECEC), Vol. 2, SAE, 1985, pp. $2.202-2.207$.
2. Maskalick, N.J., "High-Temperature Electrolysis Cell Performance Characterization," Hydrogen Energy Progress V. T.N. Veziroglu and J.B. Taylor, eds., Pergamon Press, New York, 1984, pp. 801-812.

3. Fee, D.C., et al., "Monolithic Fuel Cell Development," 1986 National Fuel Cell Seminar Abstracts, Courtesy Associates, Washington, D.C, 1986, pp. 40-43.

4. McPheeters, C.C., et a l., "Fabrication of a Solid Oxide Fuel Cell Monolithic Structure," 1986 National Fuel Cell Seminar Abstracts, Courtesy Associates, Washington, D.C., 1986, pp. 44-47.

5. Scott-Monck, J., and P. Stella, "Current Status of Advanced Solar Array Technology Development," Energy for the Twenty-first Century (20th IECEC), Vol. 1, SAE, 1985, pp. 1.32-1.35.

6. Glasstone, S., The Book of Mars, NASA SP-179, NASA, Washington, D.C., 1968.

7. Rasmussen, J.R., "Development of an Advanced Sodium/Mixed Suifur/Selenium Battery System for Space Power Applications," Energy for the Twenty-first Century, (20th IECEC), Vol. 1, SAE, 1985, pp. 1.309-1.314.

8. Rock, B.J., "Radiolsotope Space Power Programs," Space Power, NASA CP-2351, NASA, Washington, D.C., 1984, pp. 75-84.

TABLE 1 - SINGLE CELL PERformance

[Electrolysis Operation.]

\begin{tabular}{|c|c|c|c|}
\hline & Beginning & & Fully charged \\
\hline $\begin{array}{l}\text { Operating pressure, atm } \\
\text { Inlet moisture content, mol } \% \\
\text { Exit moisture content, mol } \% \\
\text { Water utilization, percent }\end{array}$ & $\begin{array}{r}5 \\
27.2 \\
10 \\
63.2\end{array}$ & $\begin{array}{r}50 \\
31 \\
10 \\
67.7\end{array}$ & $\begin{array}{r}100 \\
32.5 \\
10 \\
69.2\end{array}$ \\
\hline Applied voltage, $V$ & 1.525 & 1.525 & 1.525 \\
\hline $\begin{array}{l}\text { Losses } \\
\text { IR loss, mv } \\
\text { Polarization, mV } \\
\text { Reversible cell voltage, } v\end{array}$ & $\begin{array}{r}40 \\
400 \\
1.084\end{array}$ & $\begin{array}{r}40 \\
337 \\
1.148\end{array}$ & $\begin{array}{r}40 \\
318 \\
1.167\end{array}$ \\
\hline $\begin{array}{l}\text { Stack inlet temperature, } k \\
\text { Stack exit temperature, } k\end{array}$ & $\begin{array}{r}1048.5 \\
1273\end{array}$ & $\begin{array}{r}1001.5 \\
1273\end{array}$ & $\begin{array}{r}983 \\
1273\end{array}$ \\
\hline
\end{tabular}


TABLE 2 - ELECTROLYSIS CYCLE SUMMARY

\begin{tabular}{|c|c|c|c|}
\hline & Beginning & & Fully charged \\
\hline $\begin{array}{l}\text { Internal operating pressure, atm } \\
\text { Operating temperatures, } K \\
\text { Stack } \\
\text { Recirculating stream, at: } \\
\text { RPHX inlet } \\
\text { RPHX between } \\
\text { numbers } 1 \text { and } 2 \\
\text { Stack inlet } \\
\text { Stack exit } \\
\text { RPHX exhaust between } \\
\text { numbers } 2 \text { and } 1 \\
\text { Condenser inlet } \\
\text { Condenser exit } \\
\text { Oxygen stream at: } \\
\text { Stack outlet } \\
\text { RPHX between } \\
\text { numbers } 2 \text { and } 1 \\
\text { RPHX exit } \\
\text { Radiator loop }\end{array}$ & $\begin{array}{r}5 \\
1273 \\
355 \\
382 \\
1048.5 \\
1273 \\
653 \\
386 \\
355 \\
1273 \\
\\
653 \\
386 \\
305\end{array}$ & $\begin{array}{r}50 \\
1273 \\
425 \\
473.5 \\
1001.5 \\
1273 \\
789 \\
487.5 \\
425 \\
1273 \\
789 \\
487.5 \\
375\end{array}$ & $\begin{array}{r}412.5 \\
983 \\
1273 \\
\\
844 \\
535.5 \\
453 \\
1273 \\
\\
844 \\
535.5 \\
403\end{array}$ \\
\hline \multicolumn{4}{|c|}{ Performance summary at $10 \mathrm{kWe}$} \\
\hline $\begin{array}{l}\text { Recirculating stream flow, liter/min } \\
\text { Water consumption, cc/mm } \\
\text { Hydrogen production, mol/hr } \\
\text { RPHX heat load, kwt } \\
\text { Section number } 1 \\
\text { Section number } 2 \\
\text { Condenser heat load, kWt }\end{array}$ & $\begin{array}{r}345.4 \\
36.7 \\
122.360 \\
1.72 \\
4.19 \\
0.18\end{array}$ & $\begin{array}{r}338.6 \\
36.7 \\
122.352 \\
1.64 \\
2.76 \\
0.33\end{array}$ & $\begin{array}{r}336.8 \\
36.7 \\
122.348 \\
1.58 \\
2.30 \\
0.41\end{array}$ \\
\hline
\end{tabular}

TABLE 3 - SINGLE CELL PERformance

[Forward operation.]

\begin{tabular}{|l|r|r|r|}
\hline & Beginning & & Fully discharged \\
\hline Operating pressure, atm & 100 & 50 & 5 \\
Stack inlet temperature, K & 974 & 974.5 & 973.5 \\
Stack exit temperature, K & 1273 & 1273 & 1273 \\
Inlet moisture content, mol \% & 10 & 10 & 10 \\
Exit moisture content, mol \% & 32.5 & 31 & 27.2 \\
Hydrogen utilization, percent & 25 & 23.33 & 19.11 \\
Reversible voltage, V & 1.086 & 1.071 & 1.018 \\
IR loss, mv & 40 & 40 & 40 \\
Output voltage, $V$ & 1.046 & 1.031 & 0.978 \\
\hline
\end{tabular}


TABLE 4 - FORWARD CYCLE SUMMARY

[Fue 1 ce11.]

\begin{tabular}{|c|c|c|c|}
\hline & Beginning & & Fully discharged \\
\hline $\begin{array}{l}\text { Internal operating pressure, atm } \\
\text { Operating temperatures, } k \\
\text { Stack } \\
\text { Recirculating stream, at: } \\
\text { RPHX inlet } \\
\text { Stack inlet } \\
\text { Stack exit } \\
\text { Condenser inlet } \\
\text { Condenser exit } \\
\text { Oxygen stream at: } \\
\text { RPHX inlet } \\
\text { Stack inlet } \\
\text { Radiator loop }\end{array}$ & $\begin{array}{r}100 \\
1273 \\
453 \\
974 \\
1273 \\
750 \\
453 \\
453 \\
974 \\
403\end{array}$ & $\begin{array}{r}50 \\
1273 \\
\\
425 \\
974.5 \\
1273 \\
722 \\
425 \\
\\
425 \\
974.5 \\
375\end{array}$ & $\begin{array}{r}5 \\
1273 \\
\\
355 \\
973.5 \\
1273 \\
655.5 \\
355 \\
\\
355 \\
973.5 \\
305\end{array}$ \\
\hline \multicolumn{4}{|c|}{ Performance summary at $10 \mathrm{kWe}$} \\
\hline $\begin{array}{l}\text { Recirculating stream flow, liter/min } \\
\text { Hydrogen consumption, mol/hr } \\
\text { Water production, cc/min } \\
\text { RPHX heat load, kWt } \\
\text { Condenser heat load, kWt }\end{array}$ & $\begin{array}{r}490.9 \\
178.30 \\
53.49 \\
3.91 \\
3.97\end{array}$ & $\begin{array}{r}500.7 \\
180.93 \\
54.28 \\
4.44 \\
4.29\end{array}$ & $\begin{array}{r}538.4 \\
190.74 \\
57.22 \\
6.29 \\
5.28\end{array}$ \\
\hline
\end{tabular}


TABLE 5 - MARS SURFACE COMBINED SOLAR PV/HIGH

TEMPERATURE SOLID OXIDE REGENERATIVE

FUEL CELL

POWER SYSTEM SUMMARY AT $10 \mathrm{kWe}$

\begin{tabular}{|c|c|}
\hline $\begin{array}{l}\text { Power level (delivered) } \\
\text { Shade time assumed } \\
\text { Sun time allowed } \\
\text { Required solar PV daylight Power }\end{array}$ & $\begin{array}{c}10 \mathrm{kWe} \\
13 \mathrm{hr} \\
11 \mathrm{hr} \\
29.9 \mathrm{kWe}\end{array}$ \\
\hline \multicolumn{2}{|l|}{ Component breakdown } \\
\hline $\begin{array}{l}\text { Reactants and tankage } \\
\text { Fue } 1 \text { gas } \\
\text { Tank ( } 1.32 \mathrm{~m} \text { diameter sphere) } \\
\text { 0xygen } \\
\text { Tank ( } 1.00 \mathrm{~m} \text { diameter) } \\
\text { Reactants and tankage total }\end{array}$ & $\begin{array}{r}11 \mathrm{~kg} \\
182 \mathrm{~kg} \\
42 \mathrm{~kg} \\
84 \mathrm{~kg} \\
319 \mathrm{~kg}\end{array}$ \\
\hline \multicolumn{2}{|c|}{$\begin{array}{l}\text { Converter unit (prism } 50 \mathrm{~cm} \text { diameter by } 80 \mathrm{~cm} \\
\text { height) }\end{array}$} \\
\hline $\begin{array}{l}\text { SOFC stack ( } 10 \text { by } 10 \text { by } 46 \mathrm{~cm} \text { ) } \\
\text { Reactant preheat } H X^{\prime} \mathrm{s} \\
\text { High temperature } \\
\text { insulation package } \\
\text { Condenser } \mathrm{HX} \\
\text { Low temperature } \\
\text { section ancillaries } \\
\text { Structure and containment } \\
\text { Converter unit total } \\
\text { External radiator } \\
\text { Solar PV panel and mounts } \\
\text { Total }\end{array}$ & $\begin{array}{r}20 \mathrm{~kg} \\
5.3 \mathrm{~kg} \\
6 \mathrm{~kg} \\
1.5 \mathrm{~kg} \\
38 \mathrm{~kg} \\
36 \mathrm{~kg} \\
107 \mathrm{~kg} \\
91 \mathrm{~kg} \\
300 \mathrm{~kg} \\
817 \mathrm{~kg}\end{array}$ \\
\hline
\end{tabular}

TABLE 6 - ANL MOD 0 MONOLITH SOFC PHYSICAL

AND PERFORMANCE PARAMETERS

\begin{tabular}{|l|r|}
\hline Dimensions & \\
Cell height & $2 \mathrm{~mm}$ \\
Flow length and stack width & $10 \mathrm{~cm}$ \\
(crossflow configuration) & $0.25 \mathrm{~mm}$ \\
Electrode layer thickness & $0.025 \mathrm{~mm}$ \\
Electrolyte layer thickness & $0.025 \mathrm{~mm}$ \\
Interconnect thickness & \\
Stack active surface to volume ratio & $3.3 \mathrm{~cm}^{2} / \mathrm{cm}^{3}$ \\
Active cell density & $3.021 \mathrm{~g} / \mathrm{cm}^{3}$ \\
Current density & $500 \mathrm{ma}^{2}$ \\
Volumetric power density & $1.6 \mathrm{~W} / \mathrm{cm}^{3}$ \\
Specific weight & $2 \mathrm{~kg} / \mathrm{kWe}^{2}$ \\
\hline
\end{tabular}




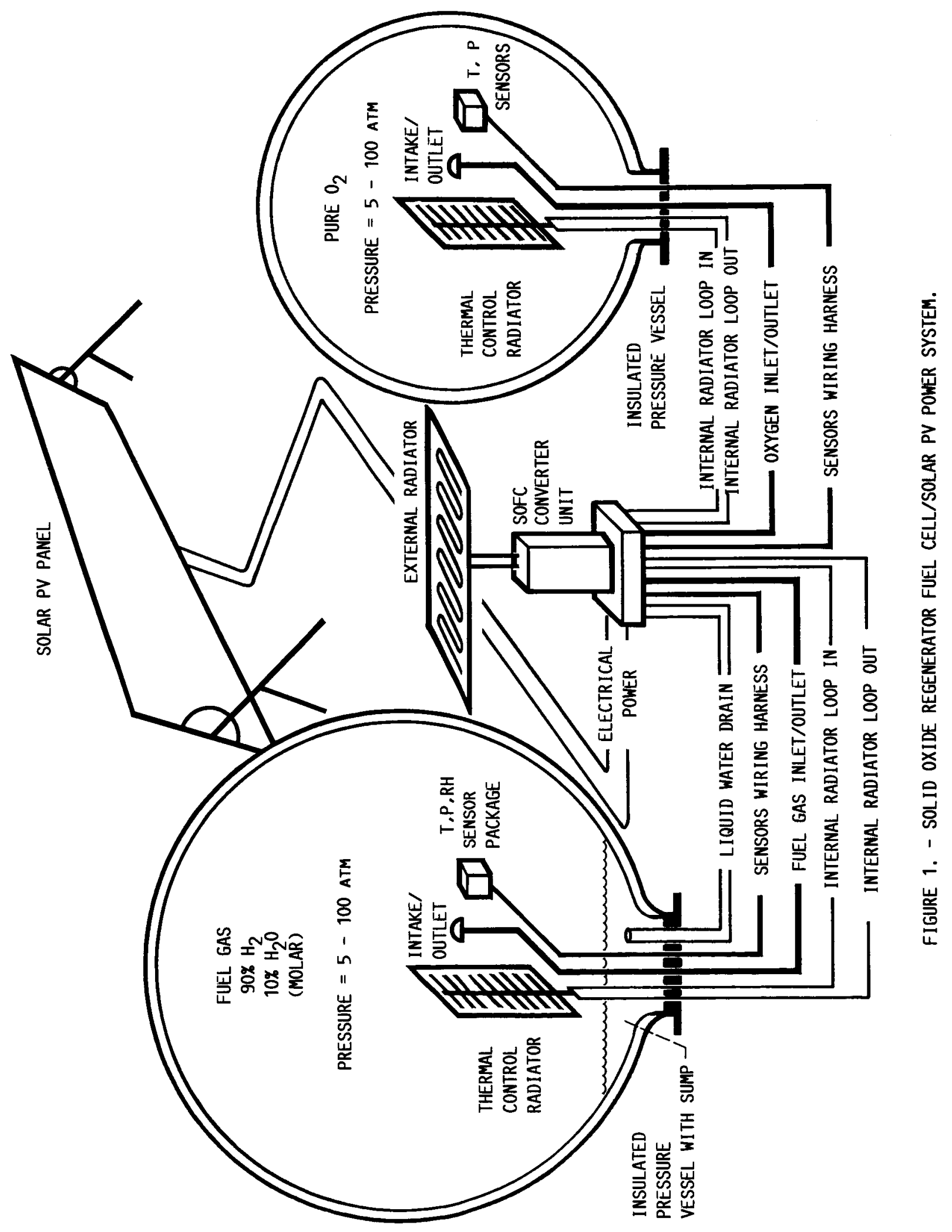




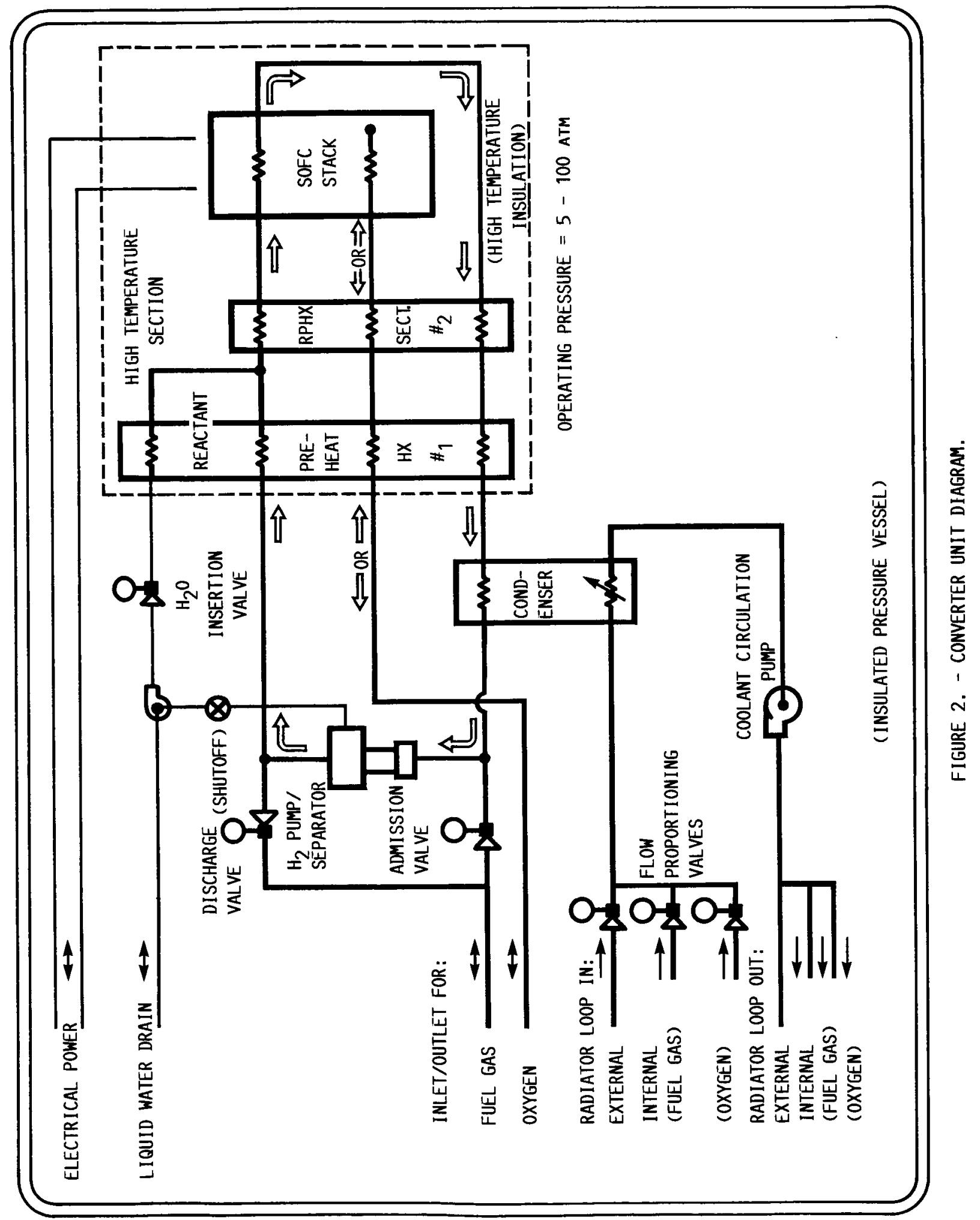




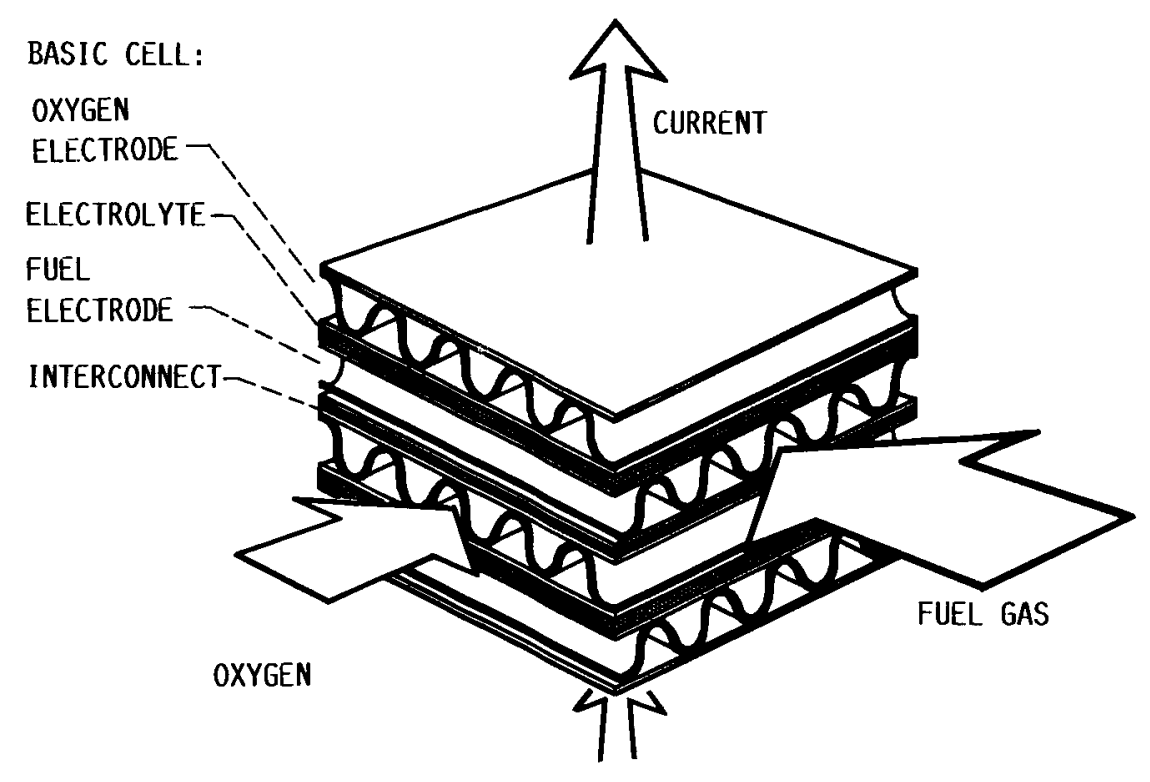

FIGURE 3. - ANL MOD. ZERO SOFC. 


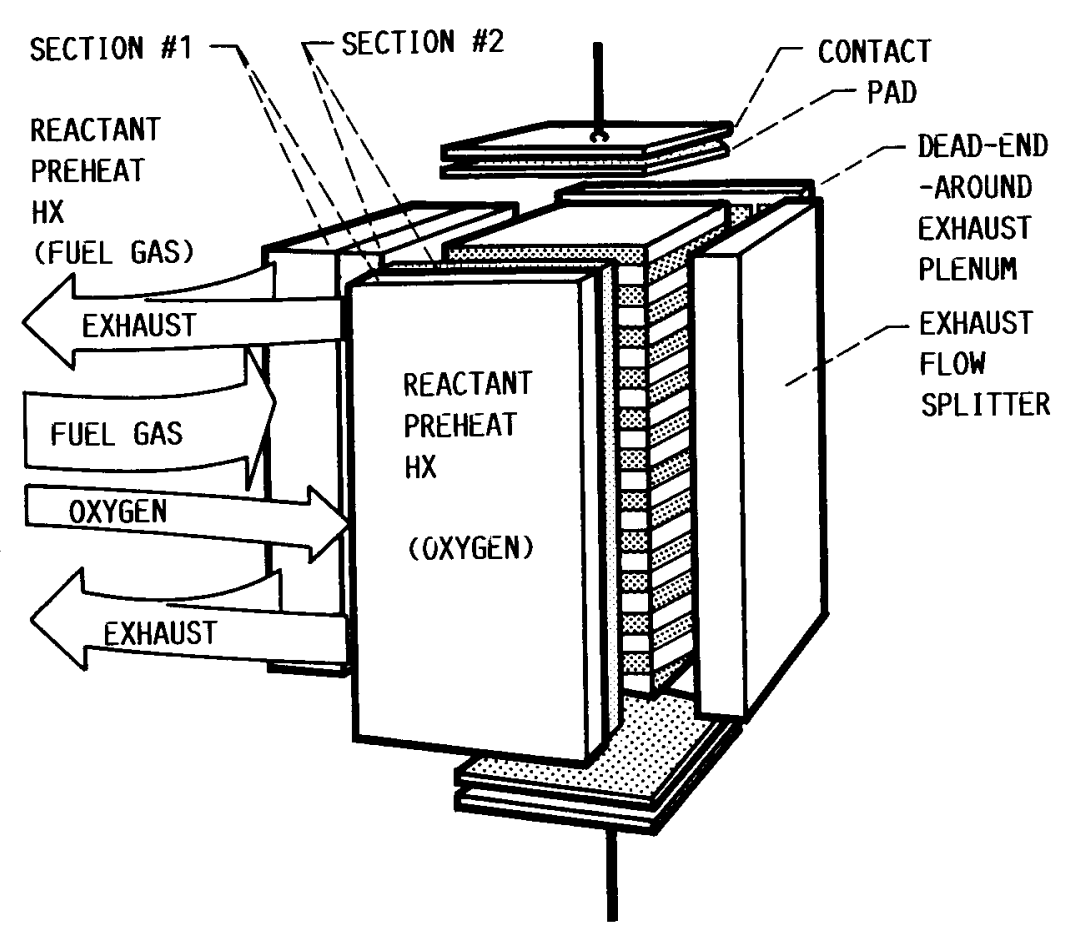

(A) INTEGRATION.

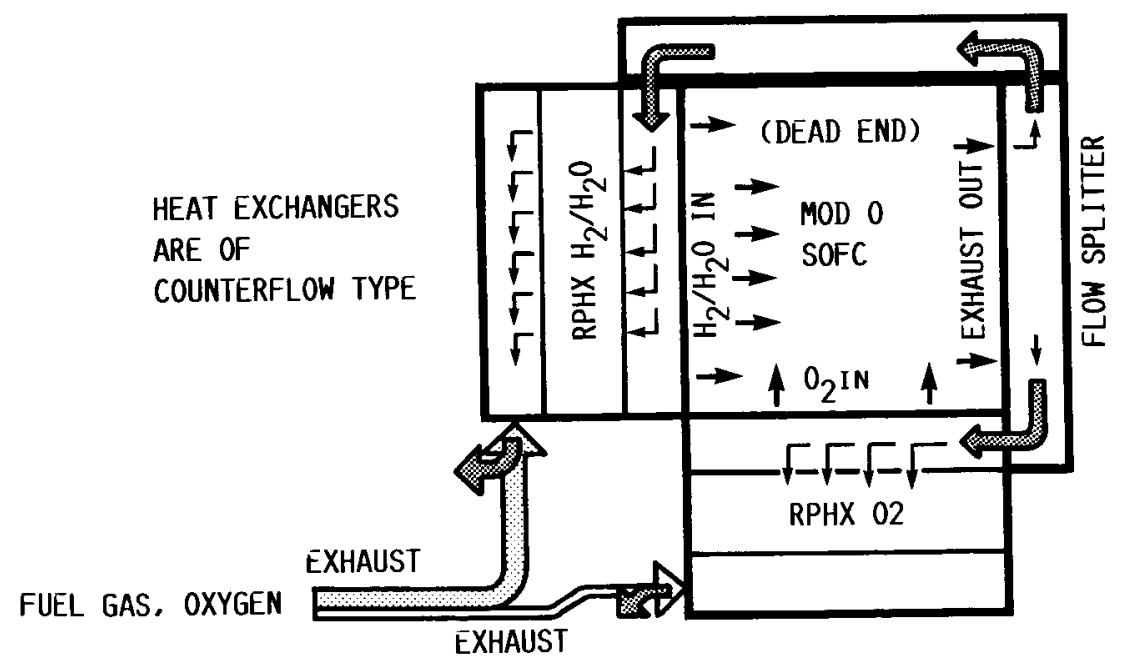

(B) FLOW PATTERN.

FIGURE 4. - STACK HEAT EXCHANGER. 


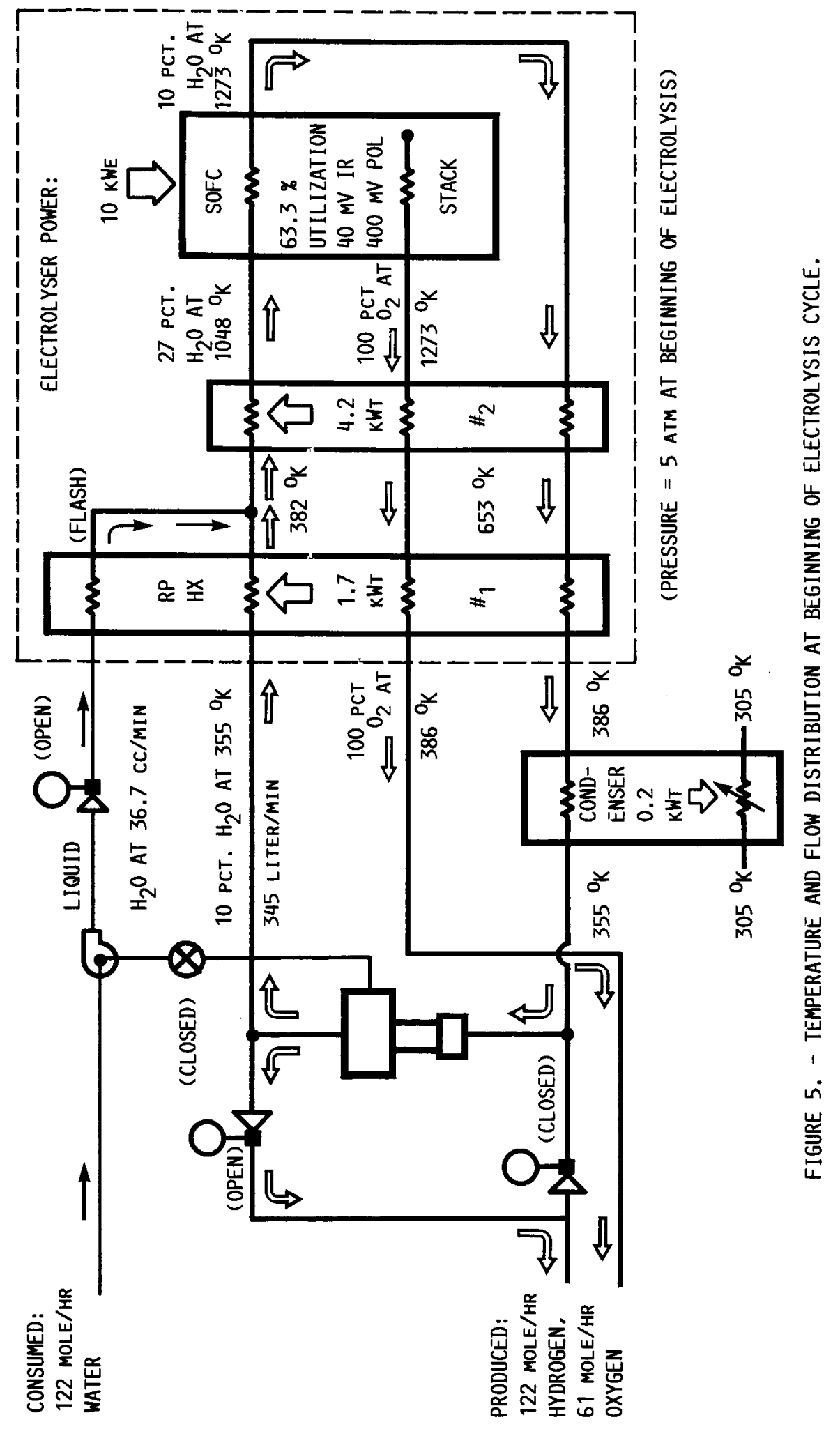




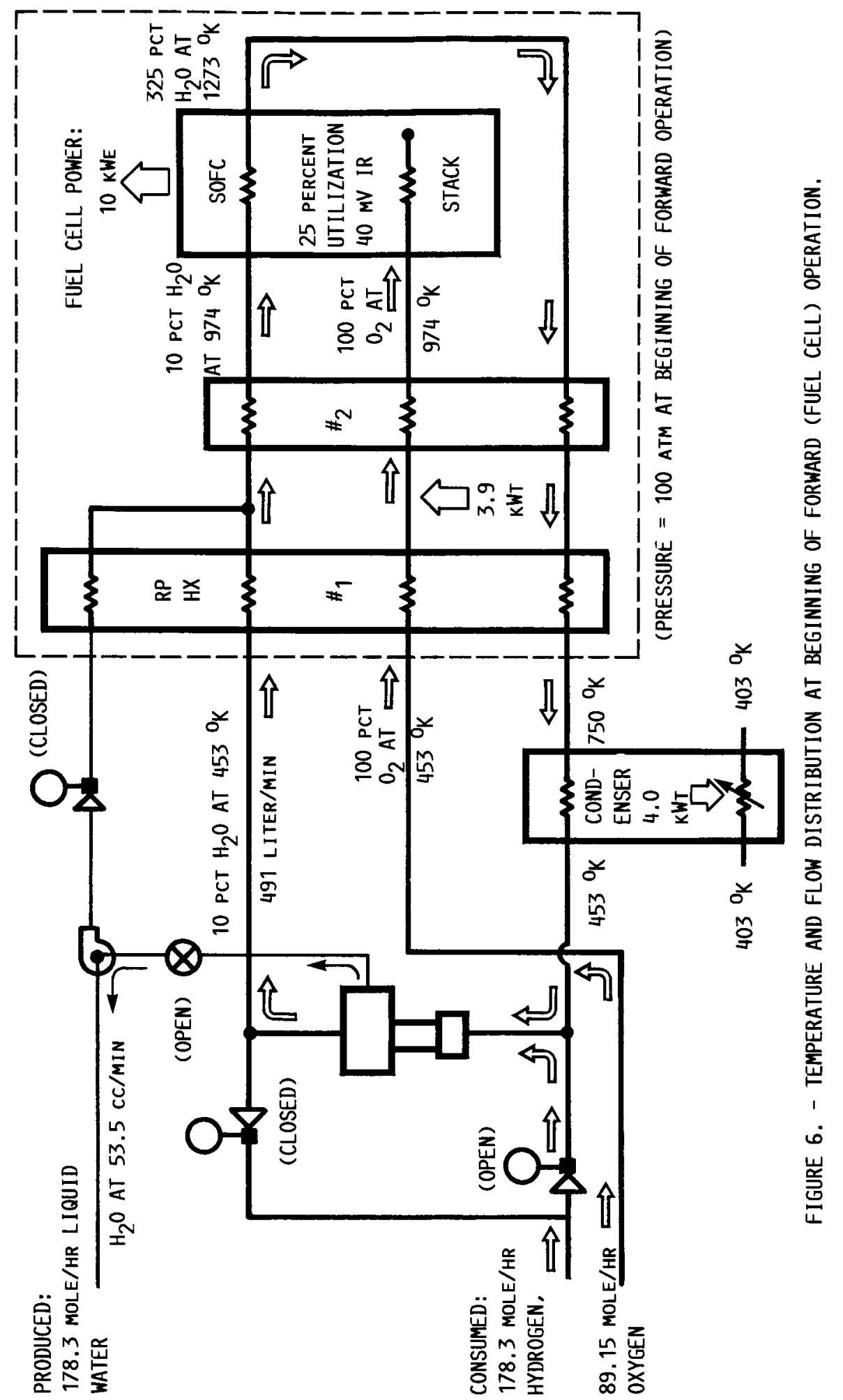




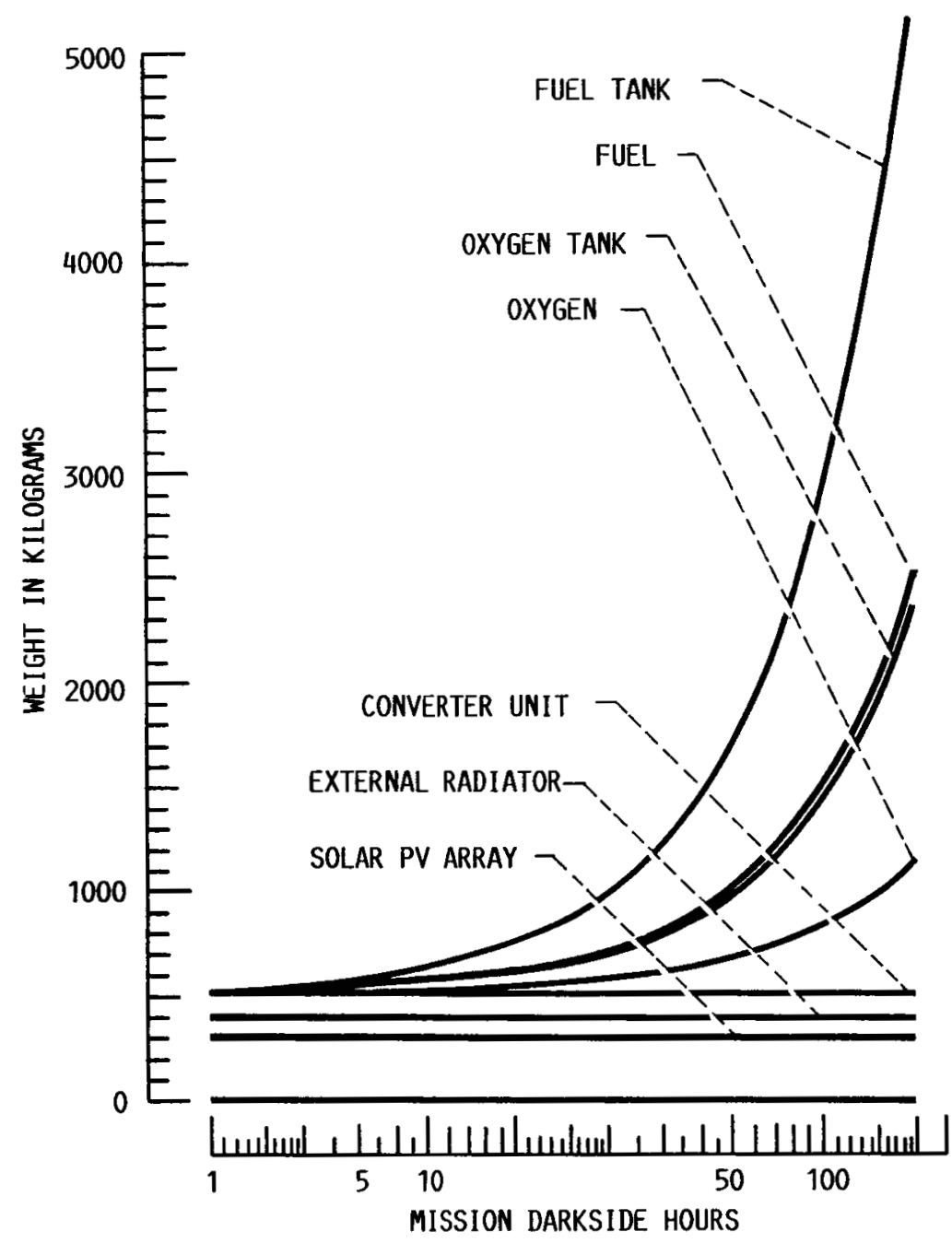

FIGURE 7. - COMBINED SOLAR PV/HIGH TEMPERATURE SOLID OXIDE REGENERATIVE FUEL CELL, MAJOR ELEMENT WEIGHT BREAKDOWN AT $10 \mathrm{KWE}$.

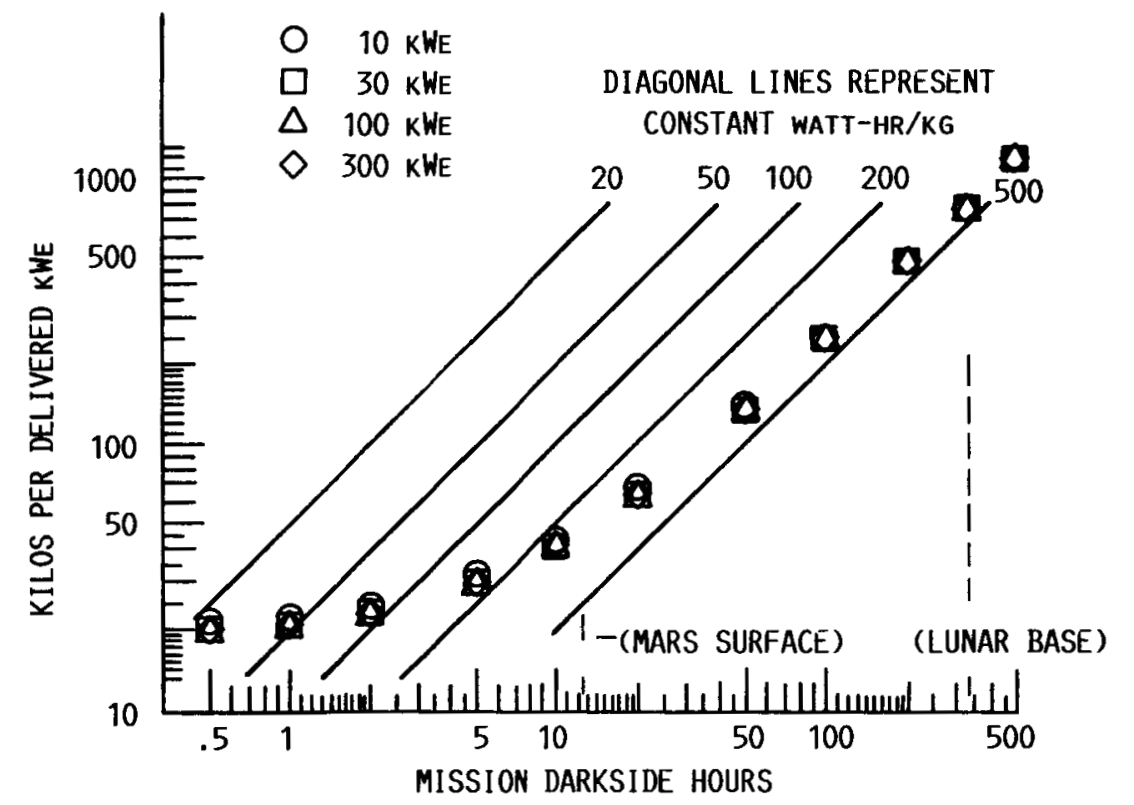

FIGURE 8. - HIGH TEMPERATURE SOLID OXIDE REGENERATIVE FUEL CELL ENERGY STORAGE SPECIFIC WEIGHT. 


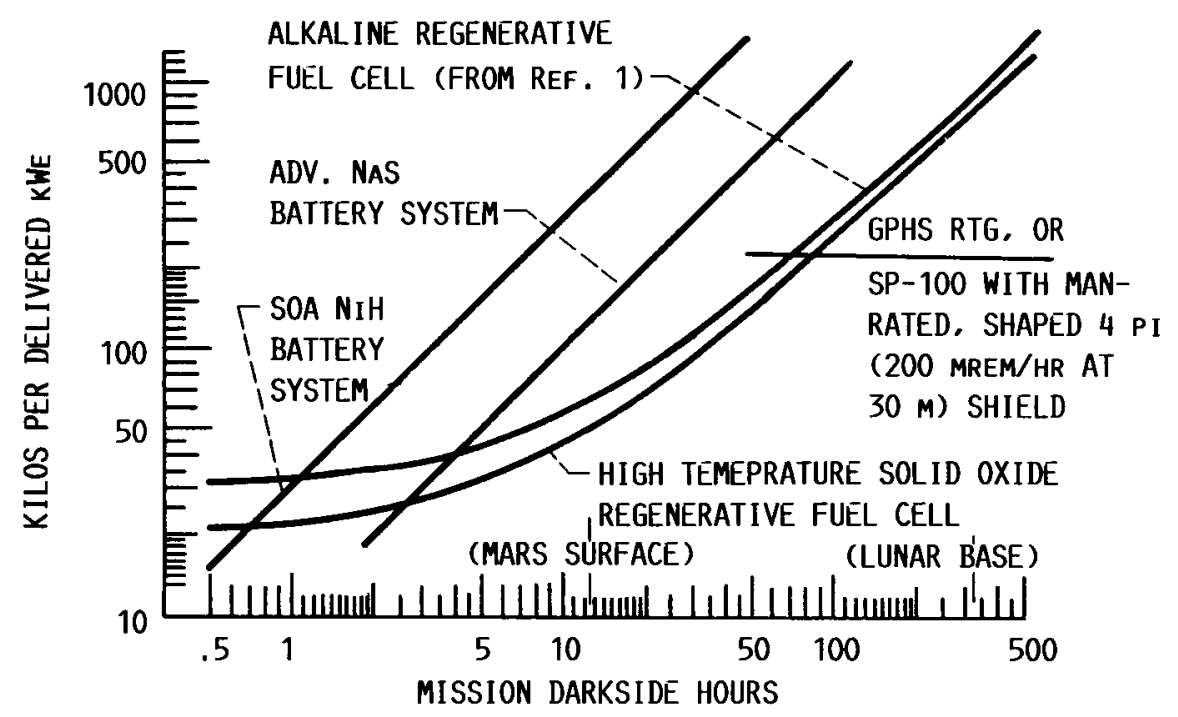

FIGURE 9. - HIGH TEMPERATURE SOLID OXIDE REGENERATIVE FUEL CELL SPECIFIC WEIGHT VERSUS COMPETITIVE DARKSIDE STORAGE. 


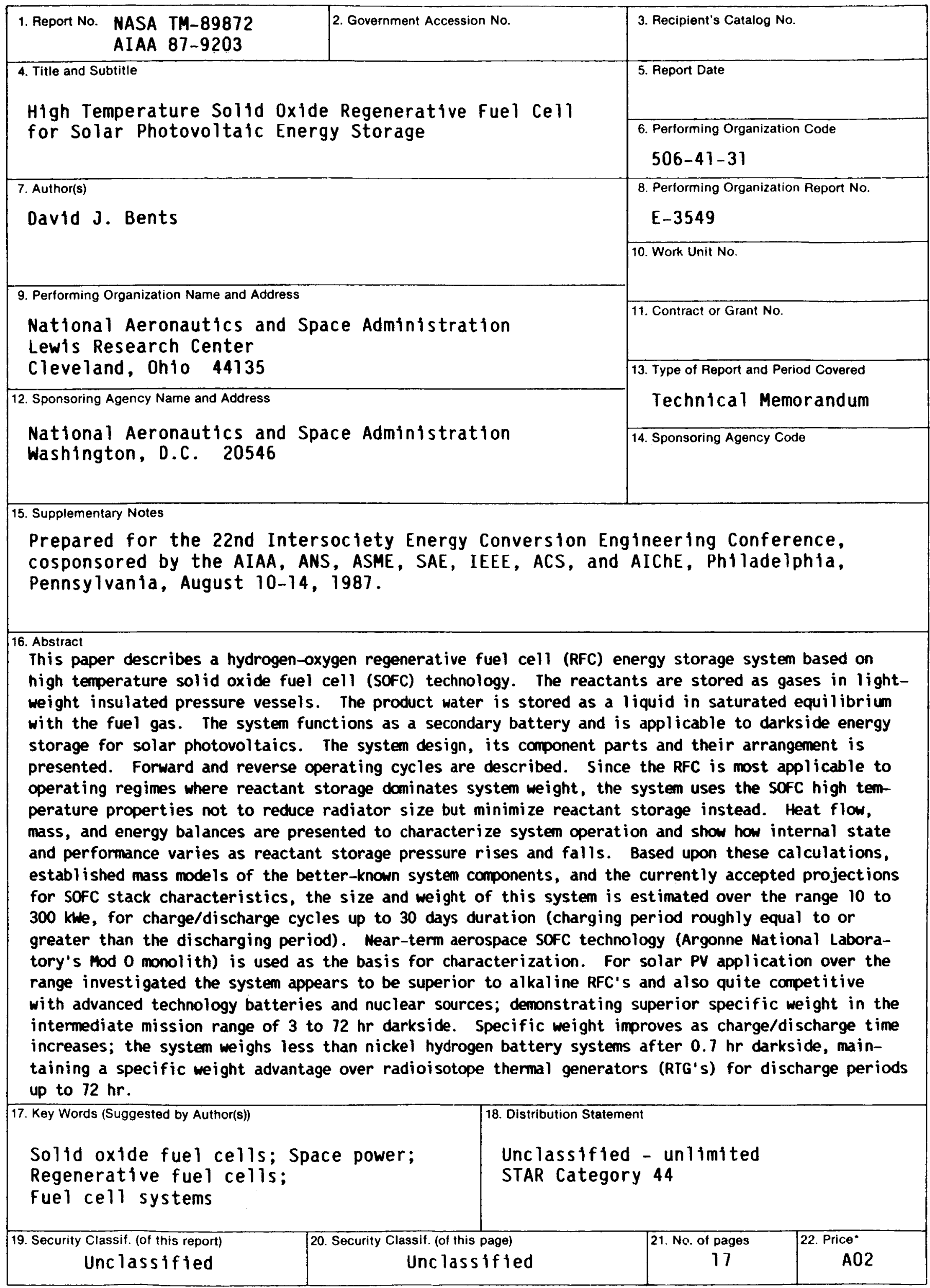

"For sale by the National Technical Information Service, Springfield, Virginia 22161 